\title{
PENINGKATAN SELF-EFFICACY MATEMATIS SISWA SMP MELALUI PEMBELAJARAN GENERATIF
}

\author{
La Moma \\ Fakultas Keguruan dan Ilmu Pendidikan Universitas Pattimura \\ email: lamoma96@yahoo.com
}

\begin{abstract}
Abstrak: Self-efficacy matematis siswa penting, maka perlu ada upaya untuk meningkatkannya. Penelitian ini menerapkan model pembelajaran generatif (MPG) sebagai alternatif pembelajaran yang diperkirakan akan memicu peningkatan kemampuan tersebut. Tujuan penelitian untuk mengetahui seberapa besar kontribusi penerapan MPG terhadap peningkatan self-efficacy baik level sekolah (tinggi, sedang dan rendah), KAM (atas, sedang rendah). Penelitian menerapkan desain kuasi eksperimen. Sampel pada penelitian ini terdiri atas 191 orang siswa kelas VIII pada tiga SMP Negeri di Kota Yogyakarta masing-masing mewakili sekolah level tinggi, sedang, dan rendah. Hipotesis penelitian diuji pada taraf signifikansi 5\%, analisis data yang digunakan uji Mann Whitney dan ANAVA dua jalur. Hasil penelitian menunjukkan (1) ada perbedaan pencapaian, peningkatan selfefficacy matematis siswa antara kelas eksperimen dan kelas control; dan (2) tidak terdapat interaksi antara pembelajaran dan level sekolah terhadap peningkatan self-efficacy matematis siswa.
\end{abstract}

Kata Kunci: self-efficacy matematis, pembelajaran generatif

\section{THE ENHANCEMENT OF JUNIOR HIGH SCHOOL STUDENTS' SELF-EFFICACY THROUGH GENERATIVE LEARNING}

\begin{abstract}
The students' mathematics self-efficacy is important. So, there must be an effort to enhance it. This study implemented the generative learning model as an instructional alternative expected to be able to enhance students' self-efficacy. This study was aimed to find out the contribution on the enhancement of the students' self-efficacy. This study employed the quasi experiment design. The sample consisted of 191 grade eight students from three state junior high schools in Yogyakarta Municipality, each representing high-level schools, medium-level schools, and low-level schools. The hypothesis was tested at the significance level of 5\%. The data were analyzed using the Mann Whitney and two-way ANOVA analyses. The findings showed that (1) there was a significant difference in the students' self-efficacy between the experimental group and the control group; (2) there was no interaction between instruction and school levels on the enhancement of the students' self-efficacy.
\end{abstract}

Keywords: mathematics self-efficacy, generative learning

\section{PENDAHULUAN}

Peneltian pada beberapa tahun terakhir tampak tidak hanya menelaah pada aspek kognitif saja, melainkan juga aspek afektif, antara lain self-efficacy yang perkirakan dapat meningkatkan kemampuan matematika siswa. Bandura (1997) mengemukakan bahwa self-efficacy merupakan suatu faktor penentu pilihan utama untuk pengembangan individu, ketekunan dalam menggunakan berbagai kesulitan, dan pemikiran memola dan reaksi-reaksi emosional yang dialami. Self-efficacy dapat dikembangkan dari diri siswa dalam pembelajaran matematika, melalui empat sumber, yaitu (1) pengalaman kinerja; (2) pengalaman orang lain; (3) aspek dukungan langsung/sosial; dan (4) aspek psikologi dan afektif.

Self-efficacy juga dituntut dalam pelaksanaan kurikulum matematika sekolah menengah pertama (SMP). Salah satu tujuan pengajaran matematika SMP (Kurikulum 2006:246) adalah mengembangkan aktivitas kreatif dan memiliki sikap menghargai kegunaan matematika dalam kehidupan, yaitu memiliki rasa ingin tahu, perhatian, dan minat dalam mempelajari mate- 
matika, serta kualitas sikap ulet, dan percaya diri (self-efficacy) dalam pemecahan masalah.

Untuk mengembangkan kemampuan selfefficacy matematis siswa, guru sebagai salah satu komponen dalam sistem pembelajaran harus mampu mengembangkan tidak hanya pada ranah kognitif dan ranah psikomotor semata yang ditandai dengan penguasaan materi pelajaran dan ketrampilan, melainkan juga ranah kepribadian siswa. Pada ranah ini, siswa harus ditumbuhkan rasa percaya dirinya (selfefficacy) sehingga menjadi manusia yang mampu mengenal dirinya sendiri yakni manusia yang berkepribadian yang mantap dan mandiri, manusia utuh yang memiliki kemantapan emosional dan intelektual, yang mengenal dirinya, mengendalikan dirinya dengan konsisten, dan memiliki rasa empati serta memiliki kepekaan terhadap permasalahan yang dihadapi baik dalam dirinya maupun dengan orang lain.

Kenyataannya di lapangan menunjukkan bahwa guru-guru matematika sekolah menengah pertama (SMP) jarang memberi perhatian yang proporsional dalam meningkatkan selfefficacy matematis siswa. Rendahnya kemampuan self-efficacy matematis siswa SMP merupakan permasalahan penting dalam pendidikan matematika. Diduga karena faktor model pembelajaran yang digunakan kurang menyenangkan, partisipasi siswa dalam pembelajaran serta lingkungan belajar yang kurang konduksif. Oleh karena itu, diperlukan suatu model pembelajaran matematika yang dipandang tepat sehingga dapat meningkatkan, self-efficacy matematis siswa tersebut.

Hasil penelitian yang dilakukan oleh Somakim (2010) pada siswa SMP di Kota Palembang dengan mengambil sampel level sekolah tinggi, sedang, dan rendah menemukan bahwa terdapat perbedaan signifikan dalam peningkatan kemampuan self-efficacy matematis siswa antara yang pembelajarannya menggunakan pendekatan matematika realistik dan pendekatan matematika biasa dan juga ditinjau dari level sekolah siswa.

Salah satu model pembelajaran yang diperkirakan dapat meningkatkan self-efficacy siswa dalam pembelajaran matematika adalah pembelajaran generatif. Pembelajaran generatif merupakan suatu model pembelajaran berbasis konstruktivisme yang lebih menekankan pada pengintegrasian secara aktif pengetahuan baru dengan menggunakan pengetahuan yang sudah dimiliki siswa sebelumnya. Model pembelajaran generatif menuntut siswa untuk aktif, dan bebas mengonstruksi pengetahuannya. Selain itu, siswa juga diberi kebebasan untuk mengungkap ide atau gagasan dan alasan terhadap permasalahan yang diberikan sehingga akan lebih memahami pengetahuan yang dibentuknya sendiri dan proses pembelajaran yang dilakukan akan lebih optimal.

Osborne \& Wittrock (1985) mengemukakan bahwa penerapan model pembelajaran generatif merupakan suatu cara yang baik untuk mengetahui pola berpikir siswa serta bagaimana siswa memahami dan memecahkan masalah dengan baik agar dalam pembelajaran nanti guru dapat menyusun strategi dalam pembelajaran, misalnya bagaimana menciptakan suasana pembelajaran yang menarik, menyenangkan, dan sebagainya.

Berdasarkan uraian di atas, dapat dikatakan bahwa pembelajaran generatif dapat memberikan tantangan kepada siswa untuk memecahkan suatu permasalahan matematis dan mendorong siswa untuk lebih kreatif, termotivasi belajar, percaya diri, serta dapat mendorong tumbuhnya self-efficacy matematis siswa. Dalam proses pembelajaran matematika guru dituntut untuk menggunakan masalah-masalah non rutin dan bersifat terbuka (open-ended) dalam penyelesaian suatu masalah dalam pembelajaran matematika.

Hasil observasi awal yang dilakukan pada beberapa SMP di Kota Yogyakarta juga menunjukkan bahwa siswa SMP dalam proses pembelajaran matematika masih banyak yang belum mampu mengungkapkan ide atau gagasannya, berkomunikasi dengan efektif, berpikir kritis, kreatif, bekerja sama dalam tim dan cenderung hanya mengikuti apa yang dicatat oleh guru di papan tulis, cenderung pasif, semangat belajarnya kurang, dan kurang rasa percaya diri saat menyampaikan pendapatnya di hadapan teman-temannya. 
Oleh karena itu, dicoba dilakukan penelitian yang berkaitan dengan self-efficacy matematis siswa dengan menggunakan model pembelajaran generatif dengan mempertimbangkan level sekolah (tinggi, sedang, rendah) siswa sekolah menengah pertama (SMP). Adapun pemasalahan yang diangkat adalah masalah: (1) pencapaian self-efficacy matematis siswa yang memperoleh pembelajaran generatif lebih baik daripada siswa yang memperoleh pembelajaran konvensional; (2) peningkatan self-efficacy matematis siswa yang memperoleh pembelajaran generatif lebih baik daripada siswa yang memperoleh pembelajaran konvensional, dan (3) interaksi antara pembelajaran (PG dan PK) dan level sekolah (tinggi, sedang, rendah) terhadap peningkatan self-efficacy matematis siswa SMP.

\section{METODE}

Penelitian ini merupakan penelitian kuasi eksperimen yang menerapkan pembelajaran generatif. Ruseffendi (2005) mengemukakan bahwa pada penelitian kuasi eksperimen subjek tidak dikelompokan secara acak, tetapi peneliti menerima keadaan subjek seadanya. Dalam penelitian ini digunakan dua kelas sebagai kelas eksperimen dan kelas kontrol, sebagai tahap awal dalam penelitian ini yaitu menentukan sampel sekolah secara random dari masingmasing sekolah level tinggi, level sedang, dan level rendah. Kemudian dari masing-masing sekolah diambil dua kelas secara acak sebagai kelas eksperimen dan satu untuk kelas kontrol. Desain penelitian yang digunakan dalam penelitian ini adalah sebagai berikut (Ruseffendi, 1994).

$\begin{array}{ccc}O & X & O \\ -0 & & 0\end{array}$

Pengelompokan subjek penelitian dilakukan secara acak kelas, kelompok eksperimen diberi perlakuan pembelajaran generatif (X), sedang kelompok kontrol diberi pembelajaran konvensional, dan selanjutnya masing-masing kelas dikenai pretes dan postes $(\mathrm{O})$. Adapun pretes dilakukan untuk melihat kesetaraan antara subjek penelitian, sedangkan postes dilaku- kan untuk mengetahui self-efficacy matematis siswa. Dalam penelitian ini juga dilibatkan faktor peringkat sekolah (tinggi, sedang, rendah) siswa, dan faktor pengetahuan awal matematika (atas, tengah, bawah) siswa.

Populasi penelitian ini adalah seluruh siswa kelas VIII SMP Negeri Kota Yogyakarta. Pemilihan siswa SMP sebagai subjek penelitian didasarkan pada pertimbangan tingkat perkembangan kognitif siswa SMP berada pada tahap peralihan dari operasi kongkret ke operasi formal sehingga dipandang tepat untuk digunakan model pembelajaran generatif. Selain itu, siswa SMP masih berada pada tahap masa remaja, dan pada masa ini siswa dalam tahap proses pencarian diri/jati diri dan pembentukan kepercayaan diri (self-efficacy).

Sampel yang terpilih pada penelitian ini adalah siswa kelas VIII SMP Negeri yang ada di Kota Yogyakarta yang terpilih dari level sekolah (tinggi, sedang, rendah) berdasarkan data dari Diknas Pendidikan Kota Yogyakarta, yaitu nilai Ujian Nasional (UN) SLTP tahun ajaran 2010/2011. Pemilihan ketiga sekolah di atas ditetapkan dengan menggunakan teknik stratified random sampling (sampel acak strata). Penetapan kelas pada setiap sekolah dilakukan dengan menggunakan teknik acak kelompok kelas.

Data dalam penelitian ini ada dua jenis, yaitu data kuantitatif dan data kualitatif. Data kuantitatif diperoleh melalui analisis terhadap jawaban siswa pada angket skala self-efficacy matematis siswa. Data kualitatif diperoleh melalui hasil observasi terhadap aktivitas guru dan siswa dalam pelaksanaan pembelajaran, data hasil wawancara dengan siswa dan guru. Data ini dianalisis secara deskriptif untuk mendukung kelengkapan data kuantitatif dalam menjawab pertanyaan penelitian. Untuk keperluan uji perbedaan digunakan uji Mann Whitney, ANOVA dua jalur, dan dilanjutkan dengan uji beda lanjut pasangan (post-hoc) melalui GLM. Keseluruhan perhitungan statistik menggunakan bantuan Program SPSS 17.0 for Windows. 
HASIL DAN PEMBAHASAN

PencapaianSelf-efficacy Matematis Siswa Berdasarkan Kelompok Pembelajaran

Analisis data untuk mengetahui pencapaian self-efficacy matematis siswa dilakukan dengan memanfaatkan skor postes self-efficacy matematis siswa dari kelompok eksperimen (MPG) dan kelompok kontrol (MPK). Data tes angket self-efficacy matematis yang berjumlah 191 orang siswa, yang terdiri atas 95 orang dari kelompok eksperimen dan 96 orang dari kelompok kontrol. Deskripsi data self-efficacy matematis siswa berdasarkan kelompok pembelajaran yang disajikan pada Tabel 1 .
Data yang diperoleh memperlihatkan bahwa rata-rata skor pencapaian self-efficacy matematis siswa yang memperoleh pembelajaran generatif (MPG) lebih baik bila dibandingkan dengan siswa yang memperoleh pembelajaran konvensional (MPK). Penyebaran data antara kedua kelompok pembelajaran tidak sama. Namun, secara keseluruhan level sekolah (tinggi, sedang, dan rendah) termasuk kategori level sedang dalam pencapaian self-efficacy matematis siswa yang memperoleh pembelajaran generatif. Deskripsi hasil pencapaian self-efficacy matematis siswa dapat disajikan Tabel 2.

Tabel 1: Deskripsi Data Pencapaian Self-Efficacy Matematis Berdasarkan Kelompok Pembelajaran

\begin{tabular}{lccccc}
\hline Kelompok & N & Rata-rata & Simp.baku & Max. & Min. \\
\hline Eksperimen & 95 & 109,988 & 11,234 & 145,92 & 72,62 \\
Kontrol & 96 & 98,649 & 7,783 & 132,25 & 79,04 \\
\hline
\end{tabular}

Keterangan: Skor maksimal ideal $=162.98$

Tabel 2: Deskripasi Data Pencapaian Self-Efficacy MatematisSiswa Berdasarkan Kelompok Pembelajaran dan Level Sekolah

\begin{tabular}{clcc}
\hline \multirow{2}{*}{$\begin{array}{c}\text { Level } \\
\text { Sekolah }\end{array}$} & Data Statistik & \multicolumn{2}{c}{ Pembelajaran } \\
\cline { 3 - 4 } & & MPG & MPK \\
& N & Postes & 31 \\
\hline \multirow{2}{*}{ Tinggi } & Rata-rata & 31 & 95,64 \\
& SB & 108,96 & 6,07 \\
& N & 13,60 & 33 \\
Sedang & Rata-rata & 33 & 100,62 \\
& SB & 110,57 & 11,79 \\
& N & 13,76 & 32 \\
\multirow{2}{*}{ Rendah } & Rata-rata & 31 & 99,53 \\
& SB & 108,90 & 6,96 \\
\hline
\end{tabular}

Keterangan: $\quad$ Skor maksimal ideal $=162,9$

Tabel 3. Hasil Uji Mann-Whitney Data Postes Self-efficacy Berdasarkan Kelompok Pembelajaran

\begin{tabular}{lcccc}
\hline Pembelajaran & $\begin{array}{c}\text { Perbedaan rata- } \\
\text { rata }\end{array}$ & $\mathrm{Z}_{\text {hitung }}$ & Sig.(2-pihak) & Ho \\
\hline MPG dengan MPK & $109,988>98,649$ & $-7,207$ & 0,000 & Ditolak \\
\hline
\end{tabular}


Kualitas hasil pencapaian self-efficacy matematis siswa antara level sekolah tinggi, sedang, dan rendah, siswa yang memperoleh pembelajaran generatif lebih besar daripada siswa yang memperoleh pembelajaran konvensioal. Selain itu, juga terlihat bahwa ratarata pencapaian Self-efficacy matematis siswa pada level sekolah sedang lebih besar daripada level sekolah tinggi dan level sekolah rendah. Dengan kata lain, level sekolah tinggi dan level sekolah rendah memperoleh ratarata skor pencapaian self-efficacy matematis adalah sama. Demikian juga halnya dengan kelas kontrol diperoleh rata-rata skor pencapaian self-efficacy matematis pada level sekolah sedang lebih besar daripada rata-rata skor pencapaian self-efficacy matematis siswa pada level sekolah tinggi dan level sekolah renda.

Namun bila, dilihat besar rata-rata skor pencapaian dari kedua kelompok pembelajaran, tampak bahwa kedua kelompok pembelajaran terjadi perbedaan, baik secara keseluruhn maupun ditinjau dari level sekolah.

Hasil uji beda menunjukkan bahwa ratarata skor postes siswa yang memperoleh pembelajaran generatif (MPK) lebih besar bila dibandingkan dengan rata-rata skor postes siswa kelompok kontrol (MPK) yang memperoleh pembelajaran konvensional sehingga dapat dikatakan bahwa ada perbedaan yang signifikan rata-rata skor postes self-efficacy matematis siswa antara kelompok eksperimen (MPG) dan kelompok kontrol (MPK). Demikian pula bila memperhatikan rata-rata skor postes kedua kelompok pembelajaran MPG dan MPK dapat disimpulkan bahwa pencapaian self-efficacy matematis siswa antara kelompok eksperimen (MPG) berbeda secara signifikan dibandingkan dengan siswa pada kelompok kontrol (MPK). Secara keseluruhan tingkat pencapaian selfefficacy matematis siswa yang memperoleh pembelajaran generatif termasuk kategori level sedang.

\section{Peningkatan Self-efficacy Matematis Siswa Berdasarkan Kelompok Pembelajaran}

Analisis data peningkatan self-efficacy matematis antara siswa menggunakan MPG dan menggunakan MPK dengan menganalisis data N-Gain secara keseluruhan dari semua level sekolah. Hasil perhitungan dari uji Mann-Whitney dari kedua kelompok data tersebut dilihat pada Tabel 4.

Tabel 4. Hasil Uji Mann-Whitney Data NGain Self-efficacy Berdasarkan Kelompok Pembelajaran

\begin{tabular}{lcccc}
\hline Pembelajaran & $\begin{array}{r}\text { Perbedaan } \\
\text { rata-rata N- } \\
\text { Gain }\end{array}$ & $\begin{array}{r}\text { Z } \\
\text { hitung }\end{array}$ & $\begin{array}{r}\text { Asymp. } \\
\text { Sig.(2- } \\
\text { pihak) }\end{array}$ & $\mathrm{H}_{\mathrm{o}}$ \\
\hline MPG dengan & $0,187>0,056$ & $-5,0810,000$ & Ditolak \\
MPK & & & &
\end{tabular}

Hasil uji menunjukkan rata-rata skor NGain self-efficacy matematis siswa kelompok eksperimen lebih besar daripada rata-rata skor N-Gain pada kelompok kontrol. Oleh karena itu, dapat disimpulkan bahwa ada perbedaan yang signifikan peningkatan self-efficacy matematis siswa antara kelompok eksperimen dengan kelompok kontrol secara keseluruhan. Selain itu, dapat dikatakan bahwa peningkatan self-efficacy matematis siswa yang memperoleh pembelajaran generatif berbeda daripada siswa yang memperoleh pembelajaran konvensional secara keseluruhan. Namun demikian, peningkatan self-efficacy matematis siswa dengan menggunakan pembelajaran generatif secara keseluruhan termasuk kategori level rendah.

\section{Interaksi antara Pembelajaran dan Level Sekolah terhadap Peningkatan Self-efficacy Matematis}

Interaksi antara pembelajaran MPG dan MPK dengan level sekolah terhadap peningkatan self-efficacy matematis siswa diperoleh dari perhitungan menggunakan uji ANOVA dua jalur melalui GLM ditunjukkan pada Tabel 5. 
Tabel 5. Hasil Uji ANOVA Dua Jalur antara Pembelajaran dan Level Sekoah terhadap Peningkatan Self-efficacy Matematis

\begin{tabular}{lllllll}
\hline Sumber & Jumlah Kuadrat & df & Rata-rata Kuadrat & F & Sig. & $\mathrm{H}_{\mathrm{o} .}$ \\
\hline Intercept & 2,163 & 1 & 2,163 & 71,297 & 0,000 & \\
Pembelajaran & 0,532 & 1 & 0,532 & 17,542 & 0,000 & Ditolak \\
Level sekolah & 0,378 & 2 & 0,189 & 6,236 & 0,000 & Ditolak \\
Pembelajaran*LS & 0,025 & 2 & 0,013 & 0,416 & 0,661 & Diterima \\
Kesalahan & 5,612 & 185 & 0,030 & & & \\
Total & 8,741 & 191 & & & & \\
\hline
\end{tabular}

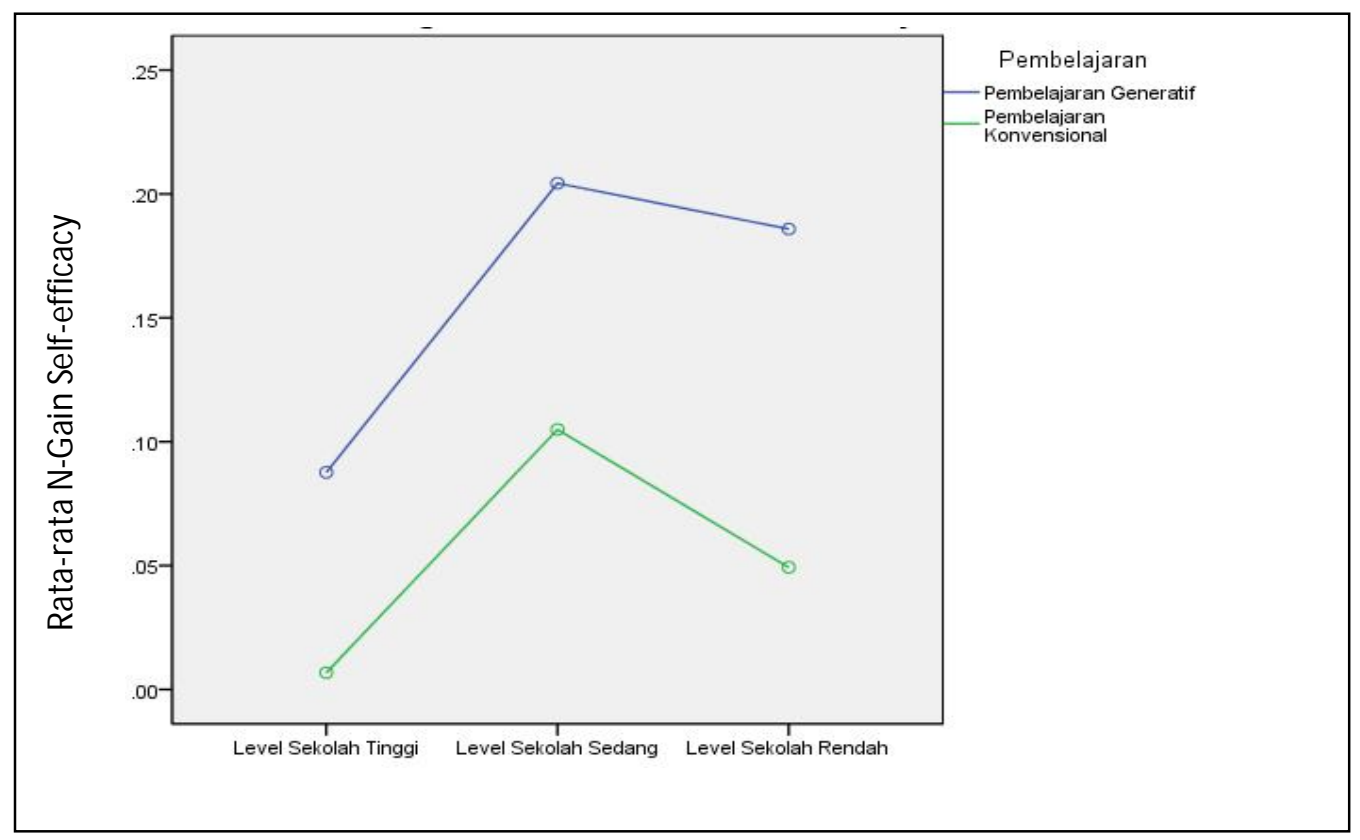

\section{Gambar 1: Interaksi antara Pembelajaran dan Level Sekolah terhadap Peningkatan Self- Efficacy Matematis}

Nilai $\mathrm{F}$ untuk pembelajaran signifikan $(0,000)$, maka dapat disimpulkan bahwa perbedaan penggunaan kelompok pembelajaran berpengaruh secara signifikan terhadap peningkatan self-efficacy matematis siswa. Nilai $\mathrm{F}$ untuk faktor level sekolah juga signifikan, maka dapat dikatakan bahwa perbedaan level sekolah berpengaruh secara signifikan terhadap peningkatan self-efficacy matematis siswa. Selain itu, juga terlihat bahwa faktor pembelajaran dan faktor level sekolah secara simultan tidak memberikan pengaruh yang signifikan terhadap peningkatan self-efficacy matematis siswa. Secara grafis dapat terlihat pada Gambar 1.

Berkaitan dengan Gambar 1 dapat dikatakan bahwa pembelajaran generatif (MPG) untuk siswa pada level sekolah sedang dan rendah cenderung lebih tinggi daripada level sekolah tinggi dalam peningkatan self-efficacy matematis siswa. Bila ditinjau secara keseluruhan dari rata-rata N-Gain self-efficacy matematis siswa yang memperoleh pembelajaran generatif (MPG) lebih besar dari rata-rata N-Gain selfefficacy matematis siswa yang menggunakan pembelajaran konvensional (MPK). Selain itu, juga tampak bahwa tidak terjadi interaksi antara level sekolah dan faktor pembelajaran dalam peningkatan self-efficacy matematis siswa. Selanjutnya, dapat dikatakan bahwa siswa level sekolah sedang cenderung tinggi peningkatan self-efficacy matematis bila dibandingkan dengan level sekolah tinggi, dan level sekolah rendah dengan menggunakan pembelajaran konvensional (MPK). Ini mengindikasikan 
bahwa siswa pada level sekolah sedang memiliki peningkatan self-efficacy matematis lebih baik bila dibandingkan dengan siswa dari level sekolah tinggi dan level sekolah rendah disebabkan karena pada level sekolah tinggi terdapat siswa yang memiliki KAM lebih tinggi dan juga pada siswa level rendah sehingga peningkatan self-efficacy matematis siswa agak sulit.

\section{Pembahasan}

\section{Pencapaian Self-efficacy Matematis Siswa}

Hasil penelitian menunjukkan bahwa terdapat perbedaan secara signifikan pencapaian self-efficacy matematis antara siswa yang memperoleh pembelajaran generatif dan siswa yang memperoleh pembelajaran konvensional. Hal ini didasarkan pada perolehan rata-rata skor postes angket self-efficacy matematis antara siswa kelas eksperimen dan kelas kontrol yang menunjukkan berbedaan signifikan sehingga memberikan dampak positif bagi siswa untuk mengembangkan pencapaian self-efficacy matematis.

Ada perebdaan rata-rata skor pencapaian self-efficacy matematis siswa untuk kelas eksperimen atau kelas yang memperoleh pembelajaran generatif memperoleh rata-rata skor pencapaian. Perbedaan kedua rata-rata skor tersebut setelah dilakukan uji statistik diperoleh bahwa terdapat perbedaan pencapaian selfefficacy matematis siswa yang memperoleh pembelajaran generatif lebih baik daripada siswa yang memperoleh pembelajaran konvensional. Dari hasil pengujian ini mengindikasikan bahwa fakor pembelajaran MPG berpengaruh secara signifikan dalam pencapaian self-efficacy matematis siswa. Ini berarti bahwa penerapan pembelajaran generatif memberikan kontribusi terhadap pencapaian self-efficacy matematis siswa, serta dipicu oleh bahan ajar matematika yang digunakan. Pembelajaran matematika yang dilakukan di kelas dengan mengacu pada karakteristik pembelajaran generatif akan memungkinkan tumbuhnya self-efficacy, dan rasa ingin tahu siswa dalam belajar matematika.

Hasil penelitian ini memperkuat dan melengkapi hasil dari temuan sebelumnya oleh
Bandura (Steven \& Arizpe, 2006) bahwa selfefficacy siswa yang muncul merupakan penentu kepercayaan diri profesional dan pilihan karier mereka. Kepercayaan diri berpengaruh positif dalam menyelesaikan masalah matematis dan tidak hanya terkait dengan pemahaman jangka pendek saja, namun juga pada pilihan karier. Hasil temuan ini sejalan dengan usaha peningkatan self-efficacy matematis siswa. Selanjutnya, hasil temuan Somakim (2010) dengan menggunakan pendekatan PMR diperoleh bahwa self-efficacy memiliki hubungan yang signifikan dengan kemampuan siswa dalam belajar matematika. Demikian juga dengan hasil penelitian Pimta, dkk. (2009) yang menemukan bahwa motivasi pencapaian memiliki efek positif terhadap pemecahan masalah siswa pada taraf signifikansi 0,05 ; hal ini karena motivasi pencapaian adalah keinginan siswa untuk melakukan lebih baik dari orang lain. Risnanosanti (2010) mengemukakan bahwa secara keseluruhan terdapat perbedaan self-efficacy terhadap matematika yang signifikan antara siswa yang mengikuti pembelajaran inkuiri dengan selfefficacy terhadap matematika siswa yang mengikuti pembelajaran biasa.

Bandura (1986) mengatakan bahwa selfefficacy akan terbangun manakala siswa berhasil mengidentifikasi kemampuan yang akan ditampilkan. Dengan demikian, pertanyaan yang diajukan guru dalam proses pembelajaran generatif akan menambah pengalaman keberhasilan siswa menyelesaikan masalah matematis.

Siswa berkemampuan matematis awal tinggi lebih banyak mempunyai pengalaman dalam menyelesaikan masalah matematis sehingga banyak menyampaikan gagasan matematis kepada teman-teman dalam kelompoknya. Pengalaman-pengalaman keberhasilan menyelesaikan masalah merupakan sumber peningkatan self-efficacy matematis, yang oleh Hamilton \& Ghatala (Prabawanto, 2012) disebut sebagai performance attainments, atau Bandura (1986) menyebutnya sebagai mastery experiences.Uraian di atas berarti menguatkan hasil penelitian bahwa pembelajaran generatif 
dapat memberikan perbedaan pencapaian selfefficacy matematis siswa secara signifikan.

\section{Peningkatan Self-Efficacy Matematis Siswa}

Hasil penelitian menunjukkan bahwa ada perbedaan yang signifikan peningkatan selfefficacy matematis antara siswa yang memperoleh pembelajaran generatif dan siswa yang memperoleh pembelajaran konvensional. Hasil temuan penelitian ini memperkuat dan melengkapi hasil-hasil temuan sebelumnya, yaitu Somakim (2010); Risnanosanti (2010) di atas. Demikian halnya dengan hasil temuan dari Chen \& Zimmerman (Champion, 2007) yang mengatakan bahwa siswa kelas 7 di Amerika serikat memiliki keyakinan diri dalam matematis jauh lebih tinggi daripada siswa kelas 6 di Taiwan.

Teori yang memperkuat hasil penelitian ini antara lain teori Bandura (1986), yaitu bahwa seseorang yang memiliki self-efficacy yang tinggi akan sangat mudah dalam melakukan tugas-tugas yang sulit lebih baik sebagai sesuatu yang harus dikuasai bukan harus dihindari. Hal yang sama juga dikemukakan oleh Pajares \& Schunk (2001), yaitu bahwa efek positif secara konsisten akan penilaian self-efficacy tentang kinerja. Self-efficacy mempengaruhi pilihan yang dibuat orang dan tindakan yang mereka inginkan. Selain itu, Bandura, (1998) mengemukakan bahwa self-efficacy dapat dibangkitkan dari diri siswa melalui empat sumber, yaitu (1) pengalaman kinerja; (2) pengalaman orang lain; (3) persuasi sosial; dan (4) keadaan emosi.

Dalam teori belajar generatif sebagaimana yang dikemukakan oleh Wittrock (1974: 182) bahwa siswa bukan penerima informasi secara pasif, melainkan siswa aktif dalam proses pembelajaran, bekerja untuk membangun pemahaman bermakna dari informasi yang diperoleh di lingkungannya. Pendapat ini sejalan dengan teori kognitif sosial Bandura. Simon (1999) mengatakan bahwa ada tiga faktor penyebab hubungan timbal balik antara perilaku individu, stimuli lingkungan, dan faktor-faktor kognitif internal. Lebih lanjut, Schraw (1998) mengatakan bahwa kognitif sosial telah ber- kembang menjadi teori yang menguat, berfokus pada menjelaskan proses-proses kognitif dan konstruksi bersifat motivasi, misalnya metakognisi. Hal yang sama, juga dikemukakan oleh Martin (2004) bahwa self-efficacy dan pengaturan diri sebagai aspek-aspek penting dalam usaha pembelajar untuk menguasai pengetahuan dan ketrampilan. Secara khusus, self-efficacy yang dirasakan atau penilaian kemampuan seseorang untuk menyelesaikan kinerja yang dipunyai dalam kontes tertentu.

Uraian di atas, menguatkan temuan hasil penelitian bahwa pembelajaran generatif dapat memberikan perbedaan peningkatan self-efficacy matematis siswa secara signifikan.

\section{Interaksi antara Pembelajaran dan Level Sekolah terhadap Peningkatan Self-efficacy Matematis Siswa}

Hasil temuan dalam penelitian ini menunjukkan bahwa interaksi antara level sekolah dan pembelajaran tidak terdapat pengaruh yang signifikan terhadap peningkatan self-efficacy matematis siswa. Hasil temuan penelitian ini mendukung dan melengkapi hasil-hasil temuan sebelumnya, antara lain Somakim (2010) mengatakan bahwa tidak terdapat interaksi antara pendekatan (PMR, PMB) dengan level sekolah (tinggi, sedang, rendah) dalam peningkatan kemampuan self-efficacy matematis siswa. Demikian pula hasil temuan Risnanosanti (2010) mengatakan bahwa tidak terdapat interaksi antara model pembelajaran (inkuiri dan biasa) dan peringkat sekolah (tinggi, sedang, dan rendah) dalam SE terhadap matematika.

Hasil temuan ini didukung dengan teori belajar sosial mengatakan bahwa perolehan keterampilan sosial yang berharga yang dikembangkan secara eksluksif atau terutama dalam kelompok sosial. Belajar sosial tergantung pada dinamika kelompok dan bagaimana individu berhasil baik atau gagal pada interaksi dinamis. Selain itu, tahapan-tahapan dalam pembelajaran generatif siswa dapat memiliki pengetahuan, kemampuan serta ketrampilan untuk mengkonstruksi pengetahuannya atau membangun pemahaman sendiri dengan menggunakan pengetahuan awal yang telah dimiliki sebelumnya 
dan menghubungkannya dengan konsep yang sedang dipelajari sehingga mampu mengkonstruksi pengetahuan baru. Hal ini akan memberikan dorongan bagi siswa dalam menumbuhkan kepercayaan diri dalam usaha untuk menyelesaikan setiap masalah yang dihadapinya dalam pembelajaran matematika. Namun, perlu disadari bahwa tidak semua siswa dalam kegiatan pembelajaran matematika dapat memenuhi apa yang telah dikemukakan di atas, hal ini terlihat pada hasil pengamatan saat kegiatan pembelajaran, siswa pada level sekolah (tinggi, dan sedang) dengan mudah dalam mengemukakan gagasan-gagasan atau ide-ide dan aktif dalam memecahkan permasalahan yang diberikan oleh guru. Bahkan, mampu berkomunikasi dengan baik antara teman dalam kelompoknya yang diberikan oleh guru.

Uraian di atas, dapat menguatkan hasil penelitian ini bahwa pembelajaran dan level sekolah (tinggi, sedang, dan rendah) secara simultan tidak dapat memberikan pengaruh yang signifikan dalam peningkatan self-efficacy matematis siswa.

Hasil penelitian juga menunjukkan bahwa perbedaan level sekolah berpengaruh secara signifikan dalam peningkatan self-efficacy matematis siswa SMP. Hasil temuan penelitian ini mendukung hasil-hasil penelitian terdahulu, antara lain Somakim (2010) mengatakan bahwa terdapat signifikansi dalam peningkatan kemampuan self-efficacy matematis siswa antara yang membelajarannya menggunakan pendekatan Matematika realistik dan pendekatan Matematika Biasa. Demikian pula, dengan hasil temuan Risnanosanti (2010) mengatakan bahwa terdapat perbedaan SE terhadap matematika yang signifikan antara siswa yang mengikuti pembelajaran inkuiri dengan SE terhadap matematika siswa yang mengikuti pembelajaran biasa untuk setiap peringkat sekolah (tinggi, sedang, dan rendah).

Selain itu, hasil temuan lain dari penelitian ini yang relevan dengan penelitian Somakim (2010), dan Risnanosanti (2010) antara lain pada pasangan level sekolah tinggi dan level sekolah sedang terdapat perbedaan yang signifikan dalam peningkatan self-efficacy ma- tematis siswa yang memeroleh pembelajaran generatif.

Perlu disadari, bahwa langkah kedua dari pembelajaran generatif, seperti yang dikemukakan oleh Osborne dan Wittrock (1985) bahwa siswa harus berani mengungkapkan ide-ide secara jelas dalam pikiran siswa. Dengan cara ini, mereka akan menyadari bahwa pada topik yang sedang dipelajari, pendapatnya berbeda dengan teman yang lain sehingga timbul konflik kognitif. Hal ini akan menimbulkan ketidakpuasan terhadap idenya dan akan mendorong siswa untuk berusaha melakukan perubahan. Selain itu, karena faktor sekolah, pembelajaran dan bahan ajar yang dikembangkan juga merupakan salah satu pemicu sehingga meningkatnya self-efficacy matematis siswa.

Fakta ini sesuai dengan pendapat Bandura (1997), yaitu bahwa self-efficacy dapat dikembangkan dalam diri siswa melalui empat sumber, yaitu: (1) pengalaman kinerja; (2) pengalaman orang lain; (3) persuasi sosial; dan (4) keadaan emosi. Siswa berkemampuan matematis awal tinggi banyak mempunyai pengalaman dalam menyelesaikan masalah-masalah matematis sehingga banyak menyampaikan gagasan atau ide matematis kepada teman-teman dalam kelompoknya. Pengalaman-pengalaman keberhasilan menyelesaikan masalah merupakan sumber peningkatan self-efficacy matematis yang oleh Hamilton \& Ghatala (Prabawanto, 2012) disebut sebagai performance attainments, sedangkan Bandura (1986) menyebutnya sebagai mastery experiences.

Berdasarkan hasil pengamatan aktivitas siswa dalam pembelajaran generatif pada tahapan ke-2, dan ke-3, yakni pengungkapan ide ini merupakan salah satu wujud pengalaman kinerja, proses penyajian hasil kerja kelompok, merupakan salah satu pengalaman orang lain, proses dalam diskusi kelompok merupakan salah satu wujud membentuk aspek sosial dan aspek psikologis.

Gambar berikut bagaimana siswa beraktivitas dalam pembelajaran yang dapat memicu tumbuhnya kemampuan self-efficacy matematis siswa di dalam kelas. 


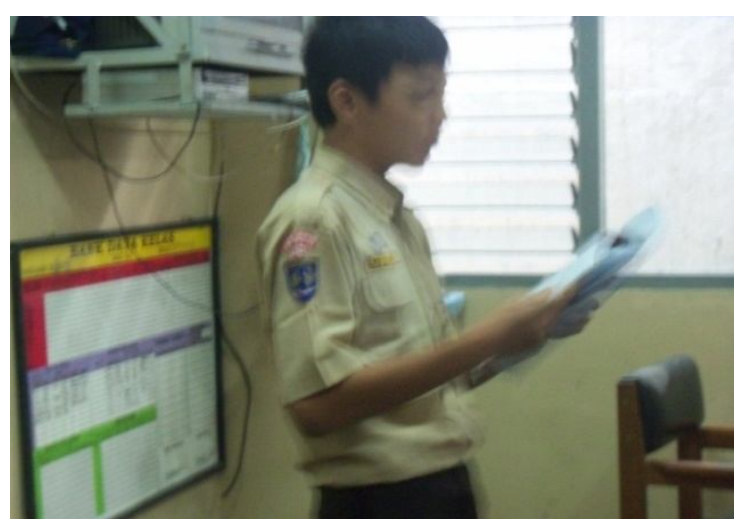

Gambar 1. Salah Seorang Siswa Mempresentasikan Hasil Kerja Kelompok

Berdasarkan Gambar 1 di atas memperlihatkan bahwa salah seorang siswa mempresentasikan hasil kerja kelompoknya di depan kelas. Tampilan siswa ini merupakan wujud dari rasa percaya diri dalam menyampaikan hasil kerja kelompok di hadapan siswa lain dan dia memiliki kemampuan berkomunikasi secara efektif. Selain itu juga menghargai pendapat orang lain bila ada pertanyaan atau saran yang disampaikan oleh siswa dari kelompok lain. Hal ini dapat menumbuhkan self-efficacy siswa dalam pembelajaran matematika, ini merupakan salah satu ciri siswa yang memiliki rasa percaya diri, kerja keras, berani tampil dalam menguraikan gagasannya, kreatif dan kritis dalam berbagai pemecahan masalah yang ia hadapi, dan tidak mudah menyerah.

Berdasarkan uraian di atas dapat dikatakan bahwa pengungkapan ide-ide siswa itu membutuhkan kemampuan komunikasi yang efektif, kerja keras, dan rasa percaya diri yang tinggi sehingga ide-ide yang baik itu bisa diwujudkan dalam bentuk pertanyaan, saran. Hal tersebut telah dilaksanakan dalam penelitian ini. Hasil ini didukung oleh hasil penelitian $\mathrm{Pa}$ lincsar \& Brown (Anderman, 2010), strategi pembelajaran yang memberikan contoh bagaimana hubungan timbal balik yang baik menggeneralisasi ide-ide baru berdasarkan pengetahuan seseorang sebelumnya dalam peningkatan self-efficacy.

\section{PENUTUP}

Berdasarkan hasil penelitian yang telah dilakukan dapat dibuat kesimpulan sebagai berikut.

- Pencapaian self-efficacy matematis siswa yang memperoleh pembelajaran generatif lebih baik daripada siswa yang memperoleh pembelajaran konvensional. Secara keseluruhan pencapaan self-efficacy matematis yang memperoleh pembelajaran generatif termasuk kategori level sedang.

- Peningkatan self-efficacy matematis siswa yang memperoleh pembelajaran generatif lebih baik dari pada siswa yang memperoleh pembelajaran konvesional. Secara keseluruhan peningkatan self-efficacy matematis dengan menggunakan pembelajaran generatif termasuk kategori level rendah.

- Tidak terdapat pengaruh interaksi antara pembelajaran dan level sekolah (tinggi, sedang, rendah) terhadap peningkatan selfefficacy matematis siswa SMP.

\section{UCAPAN TERIMA KASIH}

Ucapan terima kasih diucapkan terima kasih kepada semua pihak yang telah membantu pelaksanaan penelitian ini terutama kepada para guru di SMPN Yogyakarta yang sebagai sampel penelitian telah melayani dalam berbagai kebutuhan.

\section{DAFTAR PUSTAKA}

Anderman, E. 2010. "Reflections on Wittrock's Generative Model of Learning: A Motivation Perspective". School of Educational Policy and Leaership. The Ohio State University. Educational Psychologist, 45 (1), hlm. 55-60.

Bandura, A. 1998. Social Learning Theory. New York: General Learning Press. [Online].Tersedia: http://www.learningtheories.com/social-learning-theory-bandura-html. Diunduh 29 November 2013.

Bandura, A. 1986. Self-efficacy. [online]:Tersedia:http://www.des.emory.edumfp/ 
banEncy:html. Diunduh 24 Februari 2011.

Bandura, A. 1997. Self-efficacy The Exercise of Control. New York: W. H. Freeman.

Champion, J. 2007. Self-efficacy, Calibration, and Exam Performance in College Algebra and Calculus 1. [Online]. Tersedia: http://www.google.com/search?/hl=en\&s ource $=\mathrm{hp} \& \mathrm{q}=\quad$ champio.j.2007.self-efficacy\%clibration\&gbv=2\&oq. Diunduh 20 April 2013.

Depdiknas. 2006. Kurikulum 2006. Standar Isi Untuk Satuan Pendidikan Dasardan Menengah Mata Pelajaran Matematika. Jakarta: Depdiknas.

Martin, J. 2004. "Self-Regulated Learning, Social Cognitive Theory, and Agency". Educational Psychologist, 39(2), hlm. 135-145.

Osborne, R. J., \& Wittrock, M. C. 1985. "The Generative Learning Model and its Implication for Science Education" dalam Studies in Science Education, 12, hlm. 59-87.

Pajares, F.,\& Schunk, D. H. 2001. "Self-beliefs and School Success: Self-efficacy, Selfconcept, and School achievement". In R. Riding \& Rayner (Eds). Perception. hlm.229-266.

Pimta, S.,\& Tayruakhan, S. 2009. "Factor Influencing Mathematics Problem Solving Ability of Sixth Grade Students". Journal of Social Sciences. 5(4), hlm. 381-385.

Prabawanto, S. 2012. "Peningkatan Kemampuan Pemahaman Masalah, Komunikasi dan Self-Efficacy Matematis Mahasiswa melalui Pembelajaran dengan Pendekatan Metacognitif Scaffolding”. Disertasi Doktor pada SPS. UPI: Tidak diterbitkan.

Risnanosanti. 2010. "Kemampuan Berpikir Kreatif Matematis dan Self-Efficacy ter- hadap Matematika Siswa Sekolah Menengah Atas (SMA) dalam Pembelajaran Inkuiri”. Disertasi Doktor pada SPS. UPI: Tidak diterbitkan.

Ruseffendi, H. E. T. 1994. Statistik Dasar untuk Penelitian Pendidikan. Jakarta: Dirjen Dikti. Depdikbud.

Ruseffendi, H. E. T. 2005. Dasar-Dasar Penelitian \& Bidang Noneksata Lainnya, bagi: Peneliti, Penulis Skripsi, Tesis, Disertasi, Dosen Metode Penelitian dan Mahasiswa. Bandung: Tarsito.

Schraw, G. 1998. Promoting General Metacognitive Awareness Instructional Science, 26, 113-125.

Schunk, H. D. 2012. Learning Theory An Educational Prespective. Sixth Edition. Teori-Teori Pembelajaran: Perspektif Pendidikan. Edisi Keenam (Penerjemah Eva Hamdiah, Rahmat Fajar). Yogyakarta: Pustaka Pelajar.

Simon, S. D. 1999. "From neo-Behaviorism to Social Constructivism? The Paradigmatic Non-Evaluation of Albert Bandura". Unpublished Master's Thesis, Emory University. Retrieved, Maret 28, 2007, [Online]. Tersedia: www.des.emory.edu/mfp/simon. Diunduh 8 Agustus 2012.

Somakim. 2010. "Peningkatan Kemampuan Berpikir Kritis dan Self-Efficacy Matematik Siswa Sekolah Menengah Pertama dengan Menggunakan Pendekatan Matematika Realistik". Disertasi Doktor pada SPS. UPI: Tidak diterbitkan.

Steven, T., \& Arizpe, O.(2006. Mathematical Self-Efficacy of Middle School Students Solving The Rubric Cube. [Online] Tersedia: http://google.co. id/\#hl=Discource $=\mathrm{hpq}=$ stevent $+\mathrm{T}$. Arizpe $+\mathrm{O}+2006+$ mathematical+Selfeffficacy $+80 q=$ steven +T.Arizpe+2006+Mat. Diunduh 23 September 2010. 